\title{
Spend-and-tax: A Panel Data Investigation for the EU
}

\author{
ANTÓNIO AFONSO \\ CHRISTOPHE RAULT
}

\begin{abstract}
CESIFO WORKING PAPER No. 2705
Category 6: Fiscal Policy, Macroeconomics and Growth JULY 2009
\end{abstract}
An electronic version of the paper may be downloaded
- from the SSRN website: $\quad$ www.SSRN.com
- from the RePEc website: $\quad$ www.RePEc.org
- from the CESifo website: www.CESifo-group.org/wp




\title{
Spend-and-tax: A Panel Data Investigation for the EU
}

\begin{abstract}
Using bootstrap panel analysis, allowing for cross-country correlation, without the need of pre-testing for unit roots, we study the causality between government spending and revenue for the EU in the period 1960-2006. We find spend-and-tax causality for Italy, France, Spain, Greece, and Portugal, while tax-and-spend evidence is present for Germany, Belgium, Austria Finland and the UK, and for several EU New Member States. Moreover, in the run-up to EMU there was some shifting away from a spend-and-tax strategy, implying adjustments of fiscal behaviour.
\end{abstract}

JEL Code: C23, E62, H62.

Keywords: panel causality, fiscal policy, EU.

\author{
António Afonso \\ European Central Bank \\ Directorate General Economics \\ Kaiserstrasse 29 \\ 60311 Frankfurt am Main \\ Germany \\ antonio.afonso@ecb.europa.eu
}

\author{
Christophe Rault \\ University of Orléans \\ LEO, CNRS, UMR 6221 \\ Rue de Blois-B.P.6739 \\ 45067 Orléans Cedex 2 \\ France \\ chrault@hotmail.com \\ christophe.rault@univ-orleans.fr
}

The opinions expressed are those of the authors and do not necessarily reflect those of the ECB or the Eurosystem. 


\section{Introduction}

Fiscal sustainability studies usually assess the existence of a long-term cointegration relationship between government revenue and spending. ${ }^{1}$ Nevertheless, an important feature linked to the existence of such cointegration relation is the direction of causality between spending and revenue, which conveys how fiscal policy is set-up in practice. Indeed, one may have one-way Granger-causality from spending (revenue) to revenue (spending), i.e. "spendand-tax" ("tax-and-spend") causality, two-way causality or no Granger-causality between revenue and spending.

The literature essentially assesses the existence of causality in a single country setup. ${ }^{2}$ However, there is economic rational for undertaking a panel approach, taking advantage of non-stationary panel data econometric techniques. In the European Union (EU), and even if there is no single fiscal policy in place, panel analysis is relevant in the context of countries seeking to pursue sound fiscal policies within the framework of the Stability and Growth Pact. Cross-country dependence can be envisaged in the run-up to Economic and Monetary Union (EMU), via peer pressure or via integrated financial markets. Moreover, cross-country spillovers in government bond markets are to be expected, and interest rates comovements inside the EU have also gradually become more noticeable.

This paper contributes to the literature with a bootstrap panel analysis of causality between government revenue and spending in the EU country set, to assess which countries are characterised by a tax-and-spend or by a spend-and-tax behaviour during the period 19602006. Section two explains the methodology, section three reports the empirical analysis and section four concludes.

\section{Methodology}

We employ the panel data approach of Kónya (2006), based on a bivariate finite-order vector autoregressive model, and we apply it in our context to general government revenue, $R$, and spending, $G:^{3}$

$$
\left\{\begin{array}{l}
R_{i t}=\alpha_{1, i}+\sum_{j=1}^{p_{1 i}} \beta_{1, j, j} R_{i, t-j}+\sum_{j=1}^{p_{2 i}} \gamma_{1, i, j} G_{i, t-j}+\varepsilon_{1, i, t} t=1, \ldots, T i=1, \ldots, N \\
G_{i t}=\alpha_{2, i}+\sum_{j=1}^{p_{1 i}} \beta_{2, j, j} R_{i, t-j}+\sum_{j=1}^{p_{2 i}} \gamma_{2 i, j} G_{i, t-j}+\varepsilon_{2, j, t} t=1, \ldots, T i=1, \ldots, N
\end{array}\right.
$$

where the index $i(i=1, \ldots, N)$ denotes the country, the index $t(t=1, \ldots, T)$ the period, $j$ the lag, and $p_{1 i}, p_{2 i}$ and $p_{3 i}$, indicate the longest lags in the system. The error terms, $\varepsilon_{1, i, t}$ and $\varepsilon_{2 i, t}$, are supposed to be white- noises and may be correlated with each other for a given country.

System (1) is estimated by the Seemingly Unrelated Regressions (SUR) procedure, since possible links may exist among individual regressions via contemporaneous correlation ${ }^{4}$ within the two equations. Wald tests for Granger causality are performed with country specific bootstrap critical values generated by simulations.

\footnotetext{
${ }^{1}$ Afonso (2005) explains the relevant linkages and reviews the empirical evidence. Afonso and Rault (2007) test the cointegration relationship with panel unit root and cointegration tests, allowing for correlation within and between units.

2 See, for instance, von Fursternberg et al. (1986), Chang et al. (2002), Payne (2004), and Kollias and Paleologou (2006).

${ }^{3}$ We are grateful to L. Kónya for providing his TSP codes, which we have adapted for our analysis.

${ }^{4}$ A likely assumption for macroeconomic time series for EU countries, with strong economic links.
} 
With respect to system (1), in country $i$ there is one-way Granger-causality from $G$ to $R$ if in the first equation not all $\gamma_{1, i}$ are zero but in the second all $\beta_{2, i}$ are zero; there is one-way Granger-causality from $R$ to $G$ if in the first equation all $\gamma_{1, i}$ are zero but in the second not all $\beta_{2, i}$ are zero; there is two-way Granger-causality between $R$ to $G$ if neither all $\beta_{2, i}$ nor all $\gamma_{1, i}$ are zero; and there is no Granger-causality between $R$ to $G$ if all $\beta_{2, i}$ and $\gamma_{1, i}$ are zero. ${ }^{5}$

This procedure has several advantages. Firstly, it does not assume that the panel is homogeneous, being possible to test for Granger-causality on each individual panel member separately. However, since contemporaneous correlation is allowed across countries, it makes possible to exploit the extra information provided by the panel data setting. Secondly, it does not require pre-testing for unit roots and cointegration (since country specific bootstrap critical values are generated), though it still requires the specification of the lag structure. This is an important feature since the unit-root and cointegration tests in general suffer from low power, and different tests often lead to contradictory outcomes. Thirdly, this approach allows detecting for how many and for which members of the panel there exists one-way, two-way, or no Granger-causality.

\section{Empirical analysis}

Data for general government expenditure and revenue are taken from the European Commission AMECO database. ${ }^{6}$ The data cover the periods 1960-2006 for the EU15 countries, and 1998-2006 for the EU25 countries and the unbalanced panels are used for the SUR analysis and Granger-causality testing. ${ }^{7}$ The following panels are used: EU15 (Austria, Belgium, Denmark, Finland, France, Germany, Greece, Italy, Ireland, Luxembourg, the Netherlands, Portugal, Spain, United Kingdom, and Sweden); and EU25 (EU15 countries, Bulgaria, Czech Republic, Estonia, Hungary, Lithuania, Latvia, Malta, Poland, Slovakia and Slovenia).

We use government spending and revenue data as a ratio of GDP. Apart form the fact that ratios of nominal magnitudes are commonly used in the international debate, it is also important to scale the variables for the panel approach. In addition, the bootstrap causality test that we use does not require unit root testing.

Table 1 shows the results of the causality tests for the EU15 panel for the period 1960-2006. It is possible to observe that while government revenue positively causes government spending for Germany and negatively for Ireland, there are more cases pointing to the spend-and-tax hypothesis: Austria, France, Greece, Italy, Spain, and Sweden.

[Table1]

We also compared the results (not shown) for two sub-periods, 1960-1985 and 19862006. In the first sub-period, causality from revenue to spending occurs in six countries, while causality from spending to revenue is detected for Greece, Italy and Portugal. In addition, the tax-and-spend result is obtained for Portugal in the second sub-period while a negative causality from revenue to spending is found for Italy and Belgium, which may

\footnotetext{
${ }^{5}$ This implies a one period ahead causality.

6 The AMECO codes are as follows: total expenditure (\% of GDP), .1.0.319.0.UUTGE, .1.0.319.0.UUTGF; total revenue (\% of GDP), .1.0.319.0.URTG, .1.0.319.0.URTGF.

${ }^{7}$ For the SUR approach to work properly, the time series dimension should be substantially larger than $N$, a condition that is only fulfilled for the EU25 over the 1998-2006 period. Therefore, for the EU25 panels the SUR estimation is performed on the (unbalanced) 1970-2006 period.
} 
signal increased concerns regarding fiscal behaviour in the run-up to EMU. On the other hand, the spend-and-tax result occurs in the second sub-period for France and Ireland.

Table 2 reports the results for the EU25 country sample, considering most of the EU New Member States (NMS). The spend-and-tax result is still found for Austria, France, Greece, Italy, and Spain, and causality still runs from revenue to spending in the case of Germany and Luxembourg. On the other hand, the evidence shows causality from revenue to spending in several EU New Members States: Czech Republic, Estonia, Lithuania, and Poland. Finally, two countries exhibit two-way, bi-directional causality between government revenue and spending: Ireland and Slovakia. Table 3 summarises the causality results.

\section{[Table2]}

[Table3]

\section{Conclusion}

We used a bootstrap panel analysis of causality between government revenue and spending for the EU, which allows for contemporaneous correlation across countries and dispenses the need of pre-testing for unit roots. The results support the so-called spend-andtax causality for such countries as Italy, France, Spain, Greece, and Portugal. Tax-and-spend evidence is present notably for Germany, Belgium, Austria Finland and the UK, and also for several EU New Member States. Some changes regarding the direction of the causality patterns can also be detected, after the $2^{\text {nd }}$ half of the 1980 s, notably with countries like Greece, Italy, and Portugal, shifting away from a spend-and-tax strategy, which may imply welcome adjustments of fiscal behaviour in the run-up to EMU.

\section{References}

Afonso, A. (2005). "Fiscal Sustainability: the Unpleasant European Case", FinanzArchiv, 61(1), 19-44.

Afonso, A. and Rault, C. (2007). "What do we really know about fiscal sustainability in the EU? A panel data diagnostic", ECB Working Paper n. 820.

Chang, T.; Liu, W., Caudill, S. (2002). "Tax-and-Spend, Spend-and-Tax, or Fiscal Synchronization: New Evidence for Ten Countries," Applied Economics, 34(12), 1553 1561.

Kollias, C., Paleologou, S.-M. (2006). "Fiscal policy in the European Union: Tax and spend, spend and tax, fiscal synchronisation or institutional separation?" Journal of Economic Studies, 33(2), 108-120.

Kónya, L. (2006). "Exports and growth: Granger Causality analysis on OECD countries with a panel approach", Economic Modelling, 23(6), 978-992.

Payne, J. (2004). "The tax-spend debate: Time series evidence from state budgets", Public Choice, 95(3-4), 307-320.

von Furstenberg, G.; Green, R., Jeong, J. (1986). "Tax and spend, or spend and tax?" Review of Economics and Statistics, (68)2, 179-188. 
Table 1a - Causality from government revenue to spending, EU15 (1960-2006)

\begin{tabular}{lclccc}
\hline \hline & Estimated & Test Statistic & \multicolumn{3}{c}{ Bootstrap critical values } \\
\cline { 4 - 6 } coefficient & & $1 \%$ & $5 \%$ & $10 \%$ \\
\hline Austria & 0.1351 & 1.2361 & 26.5043 & 15.5115 & 11.5606 \\
Belgium & 0.0183 & 0.0600 & 21.6994 & 12.7869 & 8.60072 \\
Denmark & -0.0238 & 0.1362 & 24.1007 & 13.7943 & 9.80305 \\
Finland & 0.1050 & 1.6209 & 21.8583 & 13.4235 & 10.4536 \\
France & -0.0119 & 0.0153 & 33.3617 & 23.3719 & 16.5679 \\
Germany & 0.4409 & $28.130 * * *$ & 23.0660 & 14.5004 & 9.82668 \\
Greece & -0.0986 & 1.5955 & 27.2009 & 16.9224 & 12.2377 \\
Ireland & -0.2049 & $11.572 *$ & 22.1834 & 12.5130 & 9.63277 \\
Italy & 0.0003 & 0.0004 & 21.0231 & 16.4763 & 12.2038 \\
Luxembourg & 0.2337 & 6.8957 & 21.7075 & 12.2952 & 9.19950 \\
Netherlands & 0.1453 & 1.9476 & 21.0882 & 13.4699 & 9.83869 \\
Portugal & 0.1810 & 7.7905 & 29.4152 & 20.8129 & 16.4777 \\
Spain & -0.0867 & 2.4448 & 32.6605 & 23.7844 & 17.7405 \\
Sweden & 0.0281 & 0.1175 & 25.0536 & 15.5121 & 10.4427 \\
UK & 0.1628 & 3.6575 & 17.4399 & 9.79579 & 7.52149 \\
\hline \hline
\end{tabular}

***,**,*: significance at the $1 \%, 5 \%$ and $10 \%$ levels, respectively.

$\mathrm{H}_{0}: R$ does not cause $G$.

Table 1b - Causality from government spending to revenue, EU15 (1960-2006)

\begin{tabular}{llllll}
\hline \hline & Estimated & Test Statistic & \multicolumn{3}{c}{ Bootstrap critical values } \\
\cline { 3 - 5 } & coefficient & & $1 \%$ & $5 \%$ & $10 \%$ \\
\hline Austria & 0.2290 & $8.2731^{*}$ & 22.2499 & 11.1867 & 7.9895 \\
Belgium & 0.0052 & 0.0266 & 18.3643 & 10.5409 & 7.73236 \\
Denmark & 0.1307 & 3.9247 & 23.6322 & 12.5703 & 9.37391 \\
Finland & 0.0632 & 1.1145 & 18.9469 & 13.1284 & 9.68753 \\
France & 0.3230 & $25.450^{* * *}$ & 19.3738 & 14.0002 & 10.7197 \\
Germany & 0.1468 & 5.0713 & 18.5037 & 11.7241 & 8.79791 \\
Greece & 0.1043 & $12.325^{*}$ & 28.6306 & 16.7483 & 11.6541 \\
Ireland & 0.0988 & 6.3321 & 29.5567 & 12.8465 & 8.51660 \\
Italy & 0.1363 & $17.783^{* *}$ & 27.4934 & 16.1808 & 11.8194 \\
Luxembourg & 0.0806 & 0.7435 & 20.2061 & 11.3574 & 8.39400 \\
Netherlands & 0.0871 & 0.9737 & 19.4031 & 11.6964 & 8.71781 \\
Portugal & 0.1075 & 4.9057 & 26.1445 & 15.9634 & 13.1014 \\
Spain & 0.1340 & $10.590^{*}$ & 17.4415 & 11.5850 & 8.50721 \\
Sweden & 0.1285 & $8.1168^{*}$ & 15.9548 & 10.9160 & 7.76927 \\
UK & -0.0434 & 0.3727 & 20.3780 & 10.9510 & 6.97039 \\
\hline \hline
\end{tabular}

***, **, *: significance at the $1 \%, 5 \%$ and $10 \%$ levels, respectively.

$\mathrm{H}_{0}: G$ does not cause $R$. 
Table $2 \mathrm{a}$ - Causality from government revenue to spending, EU25 (1960-2006, 1998-2006 for NMS)

\begin{tabular}{llllll}
\hline \hline & Estimated & Test Statistic & \multicolumn{3}{c}{ Bootstrap critical values } \\
\cline { 3 - 5 } coefficient & & $1 \%$ & $5 \%$ & $10 \%$ \\
\hline Austria & 0.2009 & 3.6305 & 41.2461 & 23.1395 & 16.6998 \\
Belgium & -0.0010 & 0.0020 & 32.2159 & 17.9067 & 13.2455 \\
Bulgaria & 2.1296 & 1.9209 & 72.7410 & 18.1467 & 10.6635 \\
Czech Republic & 1.1902 & $117.58 * * *$ & 60.7540 & 22.8137 & 16.6407 \\
Denmark & -0.0645 & 1.3795 & 41.9757 & 22.3520 & 16.6643 \\
Estonia & 0.5861 & $116.77 * * *$ & 72.8279 & 24.2003 & 16.6886 \\
Finland & 0.1707 & 6.4720 & 46.0596 & 26.9281 & 20.8231 \\
France & 0.0676 & 0.7831 & 43.3779 & 24.2287 & 19.8115 \\
Germany & 0.4764 & $47.753 * * *$ & 34.4426 & 23.1298 & 15.8835 \\
Greece & -0.1240 & 3.3001 & 29.8829 & 19.4335 & 14.3818 \\
Hungary & 1.3929 & 13.215 & 133.850 & 33.8927 & 22.9206 \\
Ireland & -0.1863 & $10.846 *$ & 32.9529 & 16.8088 & 9.91600 \\
Italy & -0.0093 & 0.0406 & 40.0782 & 24.0417 & 18.1905 \\
Lithuania & 0.7834 & $71.052^{* * *}$ & 45.0261 & 25.1628 & 17.2383 \\
Luxembourg & 0.2527 & $11.364 *$ & 36.1252 & 17.8449 & 10.5813 \\
Latvia & -0.2954 & 0.8001 & 72.6016 & 26.0319 & 18.1718 \\
Malta & 0.1944 & 0.0612 & 66.7247 & 27.0500 & 18.7337 \\
Netherlands & 0.0917 & 1.1335 & 40.9455 & 20.3194 & 14.3195 \\
Poland & 0.7741 & $16.350 *$ & 75.7026 & 29.3214 & 16.1523 \\
Portugal & 0.1771 & 9.9942 & 66.3728 & 34.3644 & 24.1508 \\
Spain & -0.0987 & 3.6759 & 50.0771 & 32.0511 & 26.2648 \\
Slovakia & 0.8231 & $91.575 * * *$ & 47.1513 & 18.5281 & 12.4573 \\
Slovenia & 1.3726 & 0.9320 & 66.6083 & 25.8891 & 17.3368 \\
Sweden & 0.0286 & 0.1586 & 34.9508 & 18.8386 & 13.6560 \\
UK & 0.2061 & 6.7309 & 27.4755 & 14.3481 & 10.2508 \\
\hline \hline
\end{tabular}

***, **, *: significance at the $1 \%, 5 \%$ and $10 \%$ levels, respectively.

$\mathrm{H}_{0}: R$ does not cause $G$. 
Table $2 \mathrm{~b}$ - Causality from government spending to revenue, EU25 (1960-2006, 1998-2006, for NMS)

\begin{tabular}{lclcll}
\hline \hline & Estimated & Test Statistic & \multicolumn{3}{c}{ Bootstrap critical values } \\
\cline { 4 - 5 } & coefficient & & $1 \%$ & $5 \%$ & $10 \%$ \\
\hline Austria & 0.2529 & $12.044^{*}$ & 19.5303 & 13.4184 & 10.2562 \\
Belgium & 0.0224 & 0.54781 & 19.5653 & 13.9294 & 10.8562 \\
Bulgaria & 1.6730 & 1.04981 & 42.6198 & 25.0232 & 10.3543 \\
Czech Republic & -0.0349 & 0.41078 & 71.0631 & 41.1924 & 28.0181 \\
Denmark & 0.1089 & 3.27944 & 26.2961 & 19.5282 & 14.9182 \\
Estonia & -0.0841 & 2.03649 & 72.0515 & 39.0268 & 28.0185 \\
Finland & 0.0329 & 0.42829 & 21.5672 & 13.2089 & 10.1670 \\
France & 0.2434 & $18.0268^{* *}$ & 21.3095 & 13.3523 & 10.4775 \\
Germany & 0.0991 & 3.13249 & 20.9963 & 14.3719 & 10.3984 \\
Greece & 0.1141 & $19.9956^{*}$ & 28.9023 & 21.6341 & 17.0258 \\
Hungary & -0.3327 & 0.57414 & 51.9562 & 29.3867 & 18.4169 \\
Ireland & 0.1169 & $9.55691^{*}$ & 19.7658 & 12.5920 & 9.21358 \\
Italy & 0.1159 & $16.4259^{* *}$ & 22.1347 & 15.3167 & 11.6779 \\
Lithuania & -0.0018 & 0.00152 & 69.7456 & 45.8297 & 29.9929 \\
Luxembourg & 0.0927 & 1.18539 & 21.8078 & 13.8562 & 10.6759 \\
Latvia & 0.3720 & 0.78022 & 32.1787 & 21.9743 & 16.1741 \\
Malta & 0.1615 & 0.09375 & 28.1466 & 17.6842 & 10.9345 \\
Netherlands & 0.0557 & 0.48933 & 20.5256 & 14.6298 & 12.2631 \\
Poland & -0.4814 & 6.97142 & 75.3512 & 40.3326 & 28.0697 \\
Portugal & 0.1048 & 7.61307 & 30.8244 & 20.4392 & 15.4292 \\
Spain & 0.1273 & $12.0118^{*}$ & 25.0689 & 17.7928 & 11.3755 \\
Slovakia & 0.1732 & $40.8910^{* *}$ & 67.3608 & 36.4847 & 29.9371 \\
Slovenia & 0.0828 & 0.00149 & 41.5854 & 23.4056 & 14.1824 \\
Sweden & 0.1010 & 6.42458 & 18.9381 & 12.8071 & 9.37407 \\
UK & -0.0523 & 0.63520 & 18.1513 & 11.5070 & 8.34389 \\
\hline \hline
\end{tabular}

***, **, *: significance at the $1 \%, 5 \%$ and $10 \%$ levels, respectively.

$\mathrm{H}_{0}: G$ does not cause $R$.

Table 3 - Summary of results

\begin{tabular}{cccc}
\hline \multirow{2}{*}{ Panel } & \multicolumn{2}{c}{ Revenue $\Rightarrow$ Spending } & $\begin{array}{c}\text { Spending } \Rightarrow \text { Revenue } \\
\text { (spend-and-tax) }\end{array}$ \\
\cline { 2 - 4 } & $\begin{array}{c}\Delta R \Rightarrow \Delta G \\
\text { (tax-and-spend) }\end{array}$ & $\Delta R \Rightarrow \nabla G$ & $\begin{array}{c}\text { Austria, Italy, France, } \\
\text { Spain, Greece, Sweden }\end{array}$ \\
\hline EU15, 1960-2006 & Germany & Ireland & Greece, Italy, Portugal \\
\hline EU15, 1960-1985 & $\begin{array}{c}\text { Belgium, Germany, } \\
\text { Spain, Sweden, } \\
\text { Luxembourg, UK }\end{array}$ & & France, Ireland \\
\hline EU15, 1986-2006 & $\begin{array}{c}\text { Austria, Finland, } \\
\text { Portugal }\end{array}$ & $\begin{array}{c}\text { Belgium, Denmark, } \\
\text { Italy, Sweden }\end{array}$ & Slovakia, Austria, France, \\
EU25, 1960-2006; & $\begin{array}{c}\text { Czech Republic, } \\
\text { Estonia, Lithuania, } \\
\text { Poland, Slovakia } \\
\text { Germany, }\end{array}$ & Ireland & \\
& Guxembourg & & \\
& & & \\
\hline
\end{tabular}




\section{CESifo Working Paper Series}

for full list see www.cesifo-group.org/wp

(address: Poschingerstr. 5, 81679 Munich, Germany, office@cesifo.de)

2641 Martin Halla, Mario Lackner and Friedrich G. Schneider, An Empirical Analysis of the Dynamics of the Welfare State: The Case of Benefit Morale, May 2009

2642 Balázs Égert, Infrastructure Investment in Network Industries: The Role of Incentive Regulation and Regulatory Independence, May 2009

2643 Christian Gollier, Expected Net Present Value, Expected Net Future Value, and the Ramsey Rule, May 2009

2644 Sören Blomquist and Håkan Selin, Hourly Wage Rate and Taxable Labor Income Responsiveness to Changes in Marginal Tax Rates, May 2009

2645 Dominique Demougin, Oliver Fabel and Christian Thomann, Implicit vs. Explicit Incentives: Theory and a Case Study, May 2009

2646 Francesco C. Billari and Vincenzo Galasso, What Explains Fertility? Evidence from Italian Pension Reforms, May 2009

2647 Kjell Arne Brekke, Karen Evelyn Hauge, Jo Thori Lind and Karine Nyborg, Playing with the Good Guys - A Public Good Game with Endogenous Group Formation, May 2009

2648 Guglielmo Maria Caporale and Luis A. Gil-Alana, Multi-Factor Gegenbauer Processes and European Inflation Rates, May 2009

2649 Henning Bohn, A Static Model for Voting on Social Security, May 2009

2650 Markus Haavio and Kaisa Kotakorpi, The Political Economy of Sin Taxes, May 2009

2651 Augusto de la Torre, María Soledad Martínez Pería and Sergio L. Schmukler, Drivers and Obstacles to Banking SMEs: The Role of Competition and the Institutional Framework, May 2009

2652 Tobias Lindhe and Jan Södersten, Dividend Taxation, Share Repurchases and the Equity Trap, May 2009

2653 Assaf Razin and Edith Sand, Migration-Regime Liberalization and Social Security: Political-Economy Effect, May 2009

2654 Yin-Wong Cheung and Hiro Ito, A Cross-Country Empirical Analysis of International Reserves, May 2009

2655 Bart Cockx and Bruno Van der Linden, Flexicurity in Belgium. A Proposal Based on Economic Principles, May 2009 
2656 Michael Melvin, Lukas Menkhoff and Maik Schmeling, Exchange Rate Management in Emerging Markets: Intervention via an Electronic Limit Order Book, May 2009

2657 Susanne Neckermann, Reto Cueni and Bruno S. Frey, What is an Award Worth? An Econometric Assessment of the Impact of Awards on Employee Performance, May 2009

2658 Steven Brakman, Harry Garretsen and Charles van Marrewijk, Economic Geography within and between European Nations: The Role of Market Potential and Density across Space and Time, May 2009

2659 Giovanni Facchini and Cecilia Testa, Reforming Legislatures: Is one House better than two?, May 2009

2660 Carsten Kowalczyk and Raymond Riezman, Trade Agreements, May 2009

2661 Oliver Falck, Stephan Heblich and Elke Luedemann, Identity and Entrepreneurship, May 2009

2662 Christian Lessmann and Gunther Markwardt, One Size Fits All? Decentralization, Corruption, and the Monitoring of Bureaucrats, May 2009

2663 Felix Bierbrauer, On the Legitimacy of Coercion for the Financing of Public Goods, May 2009

2664 Alessandro Cigno, Agency in Family Policy: A Survey, May 2009

2665 Claudia M. Buch and Christian Pierdzioch, Low Skill but High Volatility?, May 2009

2666 Hendrik Jürges, Kerstin Schneider, Martin Senkbeil and Claus H. Carstensen, Assessment Drives Learning: The Effect of Central Exit Exams on Curricular Knowledge and Mathematical Literacy, June 2009

2667 Eric A. Hanushek and Ludger Woessmann, Schooling, Cognitive Skills, and the Latin American Growth Puzzle, June 2009

2668 Ourania Karakosta, Christos Kotsogiannis and Miguel-Angel Lopez-Garcia, Does Indirect Tax Harmonization Deliver Pareto Improvements in the Presence of Global Public Goods?, June 2009

2669 Aleksandra Riedl and Silvia Rocha-Akis, Testing the Tax Competition Theory: How Elastic are National Tax Bases in OECD Countries?, June 2009

2670 Dominique Demougin and Carsten Helm, Incentive Contracts and Efficient Unemployment Benefits, June 2009

2671 Guglielmo Maria Caporale and Luis A. Gil-Alana, Long Memory in US Real Output per Capita, June 2009 
2672 Jim Malley and Ulrich Woitek, Productivity Shocks and Aggregate Cycles in an Estimated Endogenous Growth Model, June 2009

2673 Vivek Ghosal, Business Strategy and Firm Reorganization under Changing Market Conditions, June 2009

2674 Francesco Menoncin and Paolo M. Panteghini, Retrospective Capital Gains Taxation in the Real World, June 2009

2675 Thomas Hemmelgarn and Gaëtan Nicodème, Tax Co-ordination in Europe: Assessing the First Years of the EU-Savings Taxation Directive, June 2009

2676 Oliver Himmler, The Effects of School Competition on Academic Achievement and Grading Standards, June 2009

2677 Rolf Golombek and Michael Hoel, International Cooperation on Climate-Friendly Technologies, June 2009

2678 Martin Cave and Matthew Corkery, Regulation and Barriers to Trade in Telecommunications Services in the European Union, June 2009

2679 Costas Arkolakis, A Unified Theory of Firm Selection and Growth, June 2009

2680 Michelle R. Garfinkel, Stergios Skaperdas and Constantinos Syropoulos, International Trade and Transnational Insecurity: How Comparative Advantage and Power are Jointly Determined, June 2009

2681 Marcelo Resende, Capital Structure and Regulation in U.S. Local Telephony: An Exploratory Econometric Study; June 2009

2682 Marc Gronwald and Janina Ketterer, Evaluating Emission Trading as a Policy Tool Evidence from Conditional Jump Models, June 2009

2683 Stephan O. Hornig, Horst Rottmann and Rüdiger Wapler, Information Asymmetry, Education Signals and the Case of Ethnic and Native Germans, June 2009

2684 Benoit Dostie and Rajshri Jayaraman, The Effect of Adversity on Process Innovations and Managerial Incentives, June 2009

2685 Peter Egger, Christian Keuschnigg and Hannes Winner, Incorporation and Taxation: Theory and Firm-level Evidence, June 2009

2686 Chrysovalantou Milliou and Emmanuel Petrakis, Timing of Technology Adoption and Product Market Competition, June 2009

2687 Hans Degryse, Frank de Jong and Jérémie Lefebvre, An Empirical Analysis of Legal Insider Trading in the Netherlands, June 2009

2688 Subhasish M. Chowdhury, Dan Kovenock and Roman M. Sheremeta, An Experimental Investigation of Colonel Blotto Games, June 2009 
2689 Alexander Chudik, M. Hashem Pesaran and Elisa Tosetti, Weak and Strong Cross Section Dependence and Estimation of Large Panels, June 2009

2690 Mohamed El Hedi Arouri and Christophe Rault, On the Influence of Oil Prices on Stock Markets: Evidence from Panel Analysis in GCC Countries, June 2009

2691 Lars P. Feld and Christoph A. Schaltegger, Political Stability and Fiscal Policy - Time Series Evidence for the Swiss Federal Level since 1849, June 2009

2692 Michael Funke and Marc Gronwald, A Convex Hull Approach to Counterfactual Analysis of Trade Openness and Growth, June 2009

2693 Patricia Funk and Christina Gathmann, Does Direct Democracy Reduce the Size of Government? New Evidence from Historical Data, 1890-2000, June 2009

2694 Kirsten Wandschneider and Nikolaus Wolf, Shooting on a Moving Target: Explaining European Bank Rates during the Interwar Period, June 2009

2695 J. Atsu Amegashie, Third-Party Intervention in Conflicts and the Indirect Samaritan's Dilemma, June 2009

2696 Enrico Spolaore and Romain Wacziarg, War and Relatedness, June 2009

2697 Steven Brakman, Charles van Marrewijk and Arjen van Witteloostuijn, Market Liberalization in the European Natural Gas Market - the Importance of Capacity Constraints and Efficiency Differences, July 2009

2698 Huifang Tian, John Whalley and Yuezhou Cai, Trade Sanctions, Financial Transfers and BRIC's Participation in Global Climate Change Negotiations, July 2009

2699 Axel Dreher and Justina A. V. Fischer, Government Decentralization as a Disincentive for Transnational Terror? An Empirical Analysis, July 2009

2700 Balázs Égert, Tomasz Koźluk and Douglas Sutherland, Infrastructure and Growth: Empirical Evidence, July 2009

2701 Felix Bierbrauer, Optimal Income Taxation and Public Goods Provision in a Large Economy with Aggregate Uncertainty, July 2009

2702 Marc Gronwald, Investigating the U.S. Oil-Macroeconomy Nexus using Rolling Impulse Responses, July 2009

2703 Ali Bayar and Bram Smeets, Government Deficits in the European Union: An Analysis of Entry and Exit Dynamics, July 2009

2704 Stergios Skaperdas, The Costs of Organized Violence: A Review of the Evidence, July 2009

2705 António Afonso and Christophe Rault, Spend-and-tax: A Panel Data Investigation for the EU, July 2009 